\title{
Social Support in Massive Open Online Courses: A Literature Review
}

\author{
Buyut,V.C ${ }^{1}$, Abdullah, $S^{2}$, Abdullah, $\mathbf{R}^{3}, \operatorname{Atan}, \mathbf{R}^{4}$ \\ ${ }^{1,2,3,4}$ Department of Software Engineering and Information System, \\ Faculty of Computer Science and Information Technology,Universiti Putra Malaysia \\ clement.veronica@gmail.com ${ }^{1}$
}

Article History: Received: 10 November 2020; Revised: 12 January 2021; Accepted: 27 January 2021; Published online: 05 April 2021

\begin{abstract}
Massive Open Online Courses (MOOCs) provide quality higher education resourcesfor people around the world. It allows massive number of learners to gain access to free, virtual based open educational subjects offered by accredited and world recognized top ranking institutional. However, numerous studies show that MOOCs success was marred by low completion and high dropout rates. This studyintends to identify and analyse the literature on the social support related factors influencing the utilization of MOOCs. Results from the review show that the relevant and related researchesare extremely limited which call for further studies to be done on influence of social support on MOOCs usage. The review reveals that emotional support is the most identified social support factor included in MOOC studies from various perspectives followed by informational support. Tangible support and belonging support are the least to be included in the selected studies. This review reveals that more researches are required to identify the impact of social support factors in influencing the utilization of MOOCs among learners.
\end{abstract}

Keywords:social support, massive open online courses, literature review

\section{Introduction}

Over the past decade, many higher learning institutions have embarked in the new paradigm shift of offering online courses via various formats. The online learning has never been more relevant especially during the recent outbreak of Covid-19 that struck the world. MOOCs have been the key player in cushioning the impact of the pandemic that affected industries and businesses, including educations. Top MOOC providers have offered free courses as part of their Corporate Social Responsibility program to anyone whose education has been greatly impacted by the pandemic.

Although MOOCs are currently seen as the perfect alternative to quality education, past studies showed that MOOCs are flawed with low completion and high dropout rates (Yang et al., 2013; Khalil and Ebner, 2014; Hussain et al., 2016; Liyanagunawardena et al., 2014; Veletsianos and Shepherdson, 2016). Student dropout in MOOCs is a keyinterest to be concerned about in the higher learning institutions and among policy makers which was mainly triggered by issuesbeyond the control of the institutions (Aldowah et al., 2019). Out of the $90 \%$ dropout rates, among the reasons given were due to having no one to turn to and feeling of isolation (Hew and Cheung, 2014; Khalil and Ebner, 2014).

Past studies showed the significance of social support in learning. A study on Social Support for Online Learning: Perspectives of Nursing Students (Munich, 2014) concluded that social support constructs which are informational, instrumental (tangible), emotional, and affirmational (belonging) were crucial for nursing students to achieve completion in their online courses.Preliminary findings from a research work on the role of social support for online distance learningamong rural high school students in the United states indicated that the group of students who received social support has a substantiallylesserdropout rate (Keane et al., 2008).

Social support is described as the social means that one sees as accessible orgiven to them by someone nonprofessional on the perspective of formal or informal support groups and aids (Gottlieb and Bergen, 2010). It consists of severalfactors which include emotional, instrumental (tangible), appraisal (belonging), and informational constructs (House et al., 1988; Barrera, 1986). Owing to the growing acceptance and recognition of electronic commerce and social network sites, online social support was proposedwith emphasis given mainlyto the connectionamong thereceivers and providers which includesvirtualcontacts and outsiders (Chang, 2009; Hussain, 2016b; Coulson, 2005).

So far, there has been limited studieson the systematic literature review of social support related factors that influence the use of MOOCs. This review aims to present a systematic review of the publishedresearch worksassociated to the subject in the current studies and identify research directions that can be addressed in the future. 
The review is organised along these lines: Section 2 comprises the review methodology of the systematic literature review procedure followed by Section 3 which shows the analysis of evidence to answer the research question. Section 4 depicts the discussion and lastly conclusion is shown in Section 5.

\section{Review and Methodology}

This study adopted the review strategy according to the guidelines on Systematic Literature Review (SLR) by Kitchenham and Charters (2007) and Okoli and Schabram (2010). The review process consists of three stages: planning, executing, and reporting stage.

\subsection{Planning Stage}

The planning stage activitiesconsist of identifying research context, defining review protocol, and constructing research questions. The research question (RQ) for this review is 'What are the social support related factorsproposed in the existing studies on MOOCs?

\subsection{Executing Stage}

Search strategy was done in the executing stage. The following key terms and mixed terms were used to search for relevant papers: "social support AND MOOCs", and "social support theory AND MOOCs".Papers were identified through searching two scholarly electronic databases including Scopus and Elsevier's Science Direct and Google Scholar as a supporting database. The data were extracted based on the title and abstract information. The review process considered papers published between January 2008 and May 2020. Year 2008 was selected because it was the year when the term MOOC or Massive Open Online Course was first coined. All publications are to be published in English. Papers which did not conformwith the criteria to be included in the review will be omitted.

To be included in the review, every paper must concentrate onMOOCs and not any other type of online learning or distance learning. This is because MOOCs have distinct characteristics compared to conventional online or distance learning such as the massiveness and the openness.

In the study selection process, the databases were searched using the identified key terms which returned a total of 60 related papers to be reviewed. The papers were then evaluated based on the abstract and their brief contents where duplicated and irrelevant papers were rejected. The selection process left only 29 relevant papers where filtering process was continued by employing quality assessment criteria as shown in Table 1 . The purpose of the quality assessment was to make sure selected papers were complete and useful when extracting the data. The four questions $(\mathrm{Q} 1-\mathrm{Q} 4)$ are in Table 1 with everyquestion given three responsechoices: Yes = 1; Partially $=0.5 ;$ and $\mathrm{No}=0$.

Table 1. Quality Assessment Criteria

\begin{tabular}{|l|l|l|}
\hline No. & Item & Answer \\
\hline Q1 & İs there anobviousexplanation of the aims and objectives of the study? & Yes/No/Partially \\
\hline Q2 & İs the paper described the method of analysis appropriately and sufficiently? & Yes/No/Partially \\
\hline Q3 & İs the paper supported with primary data? & Yes/No/Partially \\
\hline Q4 & Is the proposed study evidently described? & Yes/No/Partially \\
\hline
\end{tabular}

Once the quality assessment was performed based on the given criteria, the final papers were selected as shown in Table 2. 7 papers were selected with 3 papers withVery Good and 4 papers withGood ratings. Only papers with Very Good and Good ratings were chosen to be added in the review.

Table 2: Quality Assessment Results

\begin{tabular}{|l|l|l|l|l|l|}
\hline Quality Scale & Very Poor $(<1)$ & Poor $(1-<2)$ & Good $(2-<3)$ & Very Good $(3-4)$ & Total \\
\hline \# of papers & 10 & 12 & 4 & 3 & 29 \\
\hline Percentage & 35 & 41 & 14 & 10 & 100 \\
\hline
\end{tabular}




\subsection{Reporting Stage}

The chosen papers were evaluatedeven more based on theRQ in the planning stage. Data associated to the RQ are reported in the Findings section.

\section{Findings}

The findingsfrom theevaluationindicated that 7 papers were related to the subject. Although MOOCs were established since 2008, extremely limited studies were conducted on studying the influence of social support in participation of MOOCs. This can be seen from the papers selected where they were published ten years later with four out of the seven papers were published in 2019.

It is noted that some papers aimed to propose a model based on findingvariables that are used to study the influencing factors on the use of MOOCs and others were employing empirical methods to explore the factors without modelling the identified variables. The papers could be divided into two clusters:

i. Modelling the social support related variables that influence the utilization of MOOCs

ii. Not modelling the social support related variables that influence the utilization of MOOCs

The categorization of the papers is illustrated in Table 3.

Table 3.Categorization of the Identified Papers

\begin{tabular}{|l|l|}
\hline Category & Author(s) (Year) \\
\hline $\begin{array}{l}\text { i. Modelling the social } \\
\text { support related variables }\end{array}$ & $\begin{array}{l}\text { Aldowah et al., 2019; Nordina et al., 2019; Lambert, 2019; Wang et } \\
\text { al., 2020; Hsuet al., 2018 }\end{array}$ \\
\hline $\begin{array}{l}\text { ii. Not modelling the } \\
\text { social support related variables }\end{array}$ & Kellogget al., 2014; Navío-Marcoand Solórzano-García, 2019 \\
\hline
\end{tabular}

From the review exercise, nine variables were identified which were related to social support constructs. Based on social support theory, four social support constructs are tangible support, emotional support, belonging support, and informationalsupport. Table 4 shows thesocial support related variables identified from the studies while table 5 shows the classification of the variables based on social support constructs.

Table 4.Identified Variablesand the Definitions from the Selected Studies

\begin{tabular}{|l|l|l|l|}
\hline IdentifiedVariables & $\begin{array}{l}\text { Social Support } \\
\text { Constructs }\end{array}$ & Definitions & $\begin{array}{l}\text { Author(s) } \\
\text { (Year) }\end{array}$ \\
\hline $\begin{array}{l}\text { i. Perceived } \\
\text { Convenience }\end{array}$ & Tangible Support & $\begin{array}{l}\text { Flexible and more adaptable learning is } \\
\text { accessible via digital learning platform } \\
\text { which can lead to reduction in cost and time } \\
\text { saving. }\end{array}$ & $\begin{array}{l}\text { Users who are facing mental health and } \\
\text { emotional challenge can gain self } \\
\text { confidence and problem-solving capability } \\
\text { via digital learning platform. }\end{array}$ \\
\hline $\begin{array}{l}\text { ii. Computer Self } \\
\text { Community }\end{array}$ & Emotional Support \\
\hline iii. Sense & Belonging Support & $\begin{array}{l}\text { A sense of belonging, a } \\
\text { sensewhereparticipantsare relevant to each } \\
\text { other and to the group, and a mutualbelief } \\
\text { that participants'requirements and wantscan } \\
\text { befulfilledviathe obligations to be together } \\
\text { (McMillan and Chavis, 1986) }\end{array}$ \\
\hline iv. Perceived Gains & $\begin{array}{l}\text { Informational } \\
\text { Support }\end{array}$ & $\begin{array}{l}\text { The degree of conformity of standardsowed } \\
\text { to improvement and standardsobserved by } \\
\text { existing users, which is, the degree of new } \\
\text { information technology that is able to } \\
\text { satisfypresentneeds, } \\
\text { differentpriorencounters, standards, and life } \\
\text { style of users (Chen and Chen, 2015) }\end{array}$ \\
\hline v. Learner Support & $\begin{array}{l}\text { Emotional Support, } \\
\text { Tangible Support, } \\
\text { Informational } \\
\text { Support }\end{array}$ & $\begin{array}{l}\text { Supports in terms of academic, technical, } \\
\text { and motivational from teachers, counsellors, } \\
\text { colleagues, and social circles which learners } \\
\text { are already familiar with. }\end{array}$ \\
\hline
\end{tabular}




\begin{tabular}{|l|l|l|l|}
\hline $\begin{array}{l}\text { vi. Person-People } \\
\text { Misfit }\end{array}$ & $\begin{array}{l}\text { Emotional Support, } \\
\text { Belonging Support, } \\
\text { Informational } \\
\text { Support }\end{array}$ & $\begin{array}{l}\text { Person-people misfit which is a major } \\
\text { concerndue to theabsence of support from } \\
\text { peers in the utilization of ICT when } \\
\text { performing tasks at work. }\end{array}$ & $\begin{array}{l}\text { Wang et al., } \\
2020\end{array}$ \\
\hline $\begin{array}{l}\text { vii. Correspondence } \\
\text { with Peers }\end{array}$ & $\begin{array}{l}\text { Informational } \\
\text { Support, Emotional } \\
\text { Support }\end{array}$ & $\begin{array}{l}\text { The connectionsbetweenlearners and the } \\
\text { existence of acquaintances to take part in } \\
\text { mutualgroupevents }\end{array}$ & $\begin{array}{l}\text { Navío-Marco } \\
\text { and Solórzano- } \\
\text { García, 2019 }\end{array}$ \\
\hline viii. Social Support & Emotional Support & $\begin{array}{l}\text { Demonstration of understanding, affection, } \\
\text { faith, and compassion from members of the } \\
\text { family and friends. }\end{array}$ & $\begin{array}{l}\text { Nordina et al., } \\
2019\end{array}$ \\
\hline ix. Social Support & Emotional Support & $\begin{array}{l}\text { Demonstration of reassurance and } \\
\text { encouragement } \\
\text { from their teachers, colleagues, loved ones, } \\
\text { and organizationirrespective of their } \\
\text { intellectualabilities and backgrounds. }\end{array}$ & $\begin{array}{l}\text { Aldowah et al., } \\
2019\end{array}$ \\
\hline x. Peer Support & $\begin{array}{l}\text { Informational } \\
\text { Support }\end{array}$ & $\begin{array}{l}\text { Givingguidance or information to support } \\
\text { decision-making. }\end{array}$ & Kellogg et al., \\
xi. Peer Support & Tangible Support & Givingusefulsupport and resources. & 2014 \\
\hline
\end{tabular}

Table 5.Classification of Proposed Variables based on Social Support Constructs

\begin{tabular}{|l|l|}
\hline Social Support Constructs & Proposed Variables \\
\hline Tangible Support & Perceived Convenience \\
& Learner Support \\
\hline Belonging Support & Sense of Community \\
& Person-People Misfit \\
\hline \multirow{5}{*}{ Informational Support } & Perceived Gains \\
& Learner Support \\
& Person-People Misfit \\
& Correspondence with Peers \\
& Peer Support \\
\hline \multirow{5}{*}{ Emotional Support } & Computer Self Efficacy \\
& Learner Support \\
& Person-People Misfit \\
& Correspondence with Peers \\
& Social Support \\
\hline
\end{tabular}

\section{Discussions}

One of the very distinct findings from the review is the limited studies on the influence of social support factors on the use of MOOCs although MOOCs have been around since 2008. The findings of this study found various variables proposed to study the effect of social support related factors in motivating the use of MOOCs. Nine variables were identified from the review which were then classified under one of the four social support constructs which are emotional support, informational support, tangible support, and belonging support. Three of the variables could be categorized under more than one constructs. For example, learner support variable from Lambert (2019) was defined as the multidimensional support in terms of academic, technical, and motivational from teachers, mentors, peers, and social networks which could fall under emotional support, informational support, and tangible support. In the study on technostress among students in the use of technology enhanced learning by Wang et al. (2020), person-people misfit could be classified under emotional support, informational support, and belonging support. Correspondence with peers derived from Navío-Marco and Solórzano-García (2019) classified under emotional support and informational support. It is also concluded that the completion and success of a MOOC course is straightforwardly and optimisticallyassociated to the collaborationsbetweenlearners and the existence of acquaintances to participate in mutual group events (NavíoMarco and Solórzano-García, 2019).

Based on table 5, most of the identified variables were classified under emotional support. Emotional support is giving empathy, concern, affection, love, trust, intimacy, encouragement, or caring (Langford et al., 1997). This followed by informational support which is described as the provision of advice, guidance, suggestions, or 
useful information to someone (Wills, 1991). An empirical study by Lin et al., (2012) showed that informational and emotional support were the most demanded supports in online social networks.

Tangible support and belonging support were the least to be considered as social support constructs that influence the use of MOOCs from the review. Past study showed that tangible support has the minimal need in the online social networks (Liu and Hung, 2016) while belonging support is not a substantial influence and difficult to assess in the real world (Hsu et al., 2018) although it is easier to be accessed and observed in online environment (Nykvistand Mukherjee, 2016). In a review of published research works on motivational factors that influence the utilization of MOOCs for continuing professional development, it concluded that employees are motivated to use MOOCs because of social motivation (Buyut et al, 2019) which includes social connections (Loizzo et al., 2017) and perceived sense of belongings (Koukis and Jimoyiannis, 2018).

\section{Conclusion}

Social support influence in MOOCs continues to be a new topic of study, evidently proven by the limited literature found in this review. Our contribution to this area of study is mainlymotivated by the curiosity to study the influence of social support factors in the utilization of MOOCs among learners. The limitations of this study are the scarce number of researcheson social support in MOOCs specifically. Given the importance of social support factors in online learning, this work explained that social support does contribute to better learning outcome in MOOCs. Therefore, more social support factors could be considered in designing MOOCs in the future. Social support thus could be taken as an important theory to further understand MOOC learning.

\section{References}

1. Aldowah, H., Al-Samarraie, H., Alzahrani, A. I., \& Alalwan, N. (2019). Factors affecting student dropout in MOOCs: a cause and effect decision-making model. Journal of Computing in Higher Education, 1-26.

2. Barrera Jr, M. (1986). Distinctions between social support concepts, measures, and models. American journal of community psychology, 14(4), 413-445.

3. Buyut, V.C, Abdullah, S., Abdullah, R., Atan, R. (2019). Motivational Factors that Influence the Use of MOOCs for Continuing Professional Development: A Systematic Literature Review. International Journal of Advanced Science and Technology

4. Chang, H. J. (2009). Online supportive interactions: Using a network approach to examine communication patterns within a psychosis social support group in Taiwan. Journal of the American Society for Information Science and Technology, 60(7), 1504-1517.

5. Chen, Y. H., \& Chen, P. J. (2015). MOOC study group: Facilitation strategies, influential factors, and student perceived gains. Computers \& Education, 86, 55-70.

6. Coulson, N. S. (2005). Receiving social support online: an analysis of a computer-mediated support group for individuals living with irritable bowel syndrome. Cyberpsychology\&behavior, 8(6), 580-584.

7. Gottlieb, B. H., \& Bergen, A. E. (2010). Social support concepts and measures. Journal of psychosomatic research, 69(5), 511-520.

8. Hew, K. F., \& Cheung, W. S. (2014). Students' and instructors' use of massive open online courses (MOOCs): Motivations and challenges. Educational research review, 12, 45-58.

9. House, J. S., Umberson, D., \& Landis, K. R. (1988). Structures and processes of social support. Annual review of sociology, 14(1), 293-318.

10. Hsu, J. Y., Chen, C. C., \& Ting, P. F. (2018). Understanding MOOC continuance: An empirical examination of social support theory. Interactive Learning Environments, 26(8), 1100-1118.

11. Hussain, A., Mkpojiogu, E.O.C., Kamal, F.M. (2016). Antecedents to user adoption of interactive mobile maps. Journal of Telecommunication, Electronic and Computer Engineering, 8 (10), pp. 41-45.

12. Hussain, A., Mkpojiogu, E.O.C. (2016b). Requirements: Towards an understanding on why software projects fail. AIP Conference Proceedings, 1761, art. no. 020046.

13. Keane, J., de la Varre, C., Irvin, M. J., \& Hannum, W. (2008). Learner-centered social support: enhancing online distance education for underserved rural high school students in the United States.

14. Kellogg, S., Booth, S., \& Oliver, K. (2014). A social network perspective on peer supported learning in MOOCs for educators. International Review of Research in Open and Distributed Learning, 15(5), 263289.

15. Khalil, H., \& Ebner, M. (2014). MOOCs completion rates and possible methods to improve retention-A literature review. Association for the Advancement of Computing in Education (AACE), EdMedia+ innovate learning, 1305-1313. 
16. Kitchenham, B., \& Charters, S. (2007). Guidelines for performing systematic literature reviews in software engineering.

17. Koukis, N. and Jimoyiannis, A., 2018. MOOCs and Teacher Professional Development: A Case Study on Teachers' Views and Perceptions. International Association for Development of the Information Society.

18. Lambert, S. R. (2019). Six critical dimensions: A model for widening participation in open, online, and blended programs. Australasian Journal of Educational Technology, 35(6), 161-182.

19. Langford, C. P. H., Bowsher, J., Maloney, J. P., \& Lillis, P. P. (1997). Social support: a conceptual analysis. Journal of advanced nursing, 25(1), 95-100.

20. Lin, T. C., Hsu, J. S. C., Cheng, H. L., \& Chiu, C. M. (2012). Exploring Individuals' Loyalty to Online Support Groups from the Perspective Of Social Support. In PACIS, 103.

21. Liu, Y. C., \& Hung, Y. Y. (2016). Self-efficacy as the moderator: Exploring driving factors of perceived social support for mainland Chinese students in Taiwan. Computers in Human Behavior, 64, 455-462.

22. Liyanagunawardena, T. R., Williams, S., \& Adams, A. A. (2014). The impact and reach of MOOCs: a developing countries' perspective. eLearning Papers, 38-46.

23. Loizzo, J., Ertmer, P.A., Watson, W.R. and Watson, S.L., 2017. Adult MOOC Learners as SelfDirected: Perceptions of Motivation, Success, and Completion. Online Learning, 21(2), p.n2.

24. McMillan, D. W., \& Chavis, D. M. (1986). Sense of community: A definition and theory. Journal of community psychology, 14(1), 6-23.

25. Munich, K. (2014). Social Support for Online Learning: Perspectives of Nursing Students. International Journal of E-Learning \& Distance Education, 29(2), n2.

26. Navío-Marco, J., \& Solórzano-García, M. (2019). Student's social e-reputation ("karma”) as motivational factor in MOOC learning. Interactive Learning Environments, 1-15.

27. Nordina, N., Normanb, H., Zainic, H., Hamdand, F., Md, M., \&Yunuse, N. H. A. Online Innovation of Business Start-up Training for Marginalised Communities via MOOCS.

28. Nykvist, S., \& Mukherjee, M. (2016). Who am I? Developing pre-service teacher identity in a digital world. Procedia-Social and Behavioral Sciences, 217, 851-857.

29. Okoli, C., \&Schabram, K. (2010). A guide to conducting a systematic literature review of information systems research.

30. Veletsianos, G., \& Shepherdson, P. (2016). A systematic analysis and synthesis of the empirical MOOC literature published in 2013-2015. International Review of Research in Open and Distributed Learning, 17(2), 198-221.

31. Wang, X., Tan, S. C., \& Li, L. (2020). Technostress in university students' technology-enhanced learning: An investigation from multidimensional person-environment misfit. Computers in Human Behavior, 105, 106208.

32. Wills, T. A. (1991). Social support and interpersonal relationships.

33. Yang, D., Sinha, T., Adamson, D., \& Rosé, C. P. (2013, December). Turn on, tune in, drop out: Anticipating student dropouts in massive open online courses. In Proceedings of the 2013 NIPS Datadriven education workshop, Vol. 11, 14. 